\title{
HABITAT SELECTION, DISTRIBUTION AND POPULATION DENSITY OF SPHAEROMA TEREBRANS (CRUSTACEA: ISOPODA) IN THE LITTORAL SUBSOIL OF A TROPICAL ESTUARINE MANGROVE ECOSYSTEM
}

\author{
R. Sunil Kumar \\ Department of Zoology, Catholicate College, Pathanamthitta, Kerala 689645, India. \\ Email: sunilkumarr@satyam.net.in
}

\begin{abstract}
Distribution and population density of a wood borer, Sphaeroma terebrans, in detail in relation to the prevailing ecological conditions in the intertidal subsoil of a tropical mangrove biotope is the first ever described from Cochin area in Kerala. Literature survey revealed that the species was earlier reported from the exposed and submerged wooden materials of coastal waters as well as mangrove environment of India. Occurrence of Sphaeroma terebrans in the subsoil indicated the selection of a new habitat by the organism. This species was found to have penetrated $15 \mathrm{~cm}$ deep into the Cochin mangrove soil showing its burrowing potential and survival in that area. Monthly population density varied from 3 to $19 / 0.1 \mathrm{~m}^{2}$. Distribution of species in the subsoil was substantially related to the high abundance of mangrove detritus and debris within the soil. The more exposed soil of the intertidal area, in connection to the tidal cycle, was well preferred as a suitable habitat by Sphaeroma terebrans. However, the species showed inconsistent distribution pattern in that area. Physicochemical factors showed no significant correlation to the distribution, substantiating the euryhaline and other tolerance behaviour of the species. Accumulation and incorporation of cellulose materials in soil pertinently render in aggregation of sphaeromids within the mangrove substratum. The great adaptability of the species to submergence of tidal water and subsequent exposure within the subsoil together with the persistent flow and prolonged standing of vegetative materials evidently supported the habitat selection of Sphaeroma terebrans and long-term survival in the distinct and dynamic mangrove littoral area.
\end{abstract}

\section{Keywords}

Mangrove, vegetative materials, Sphaeroma terebrans, ecology, population, subsoil, Cochin

\section{Introduction}

A variety of species belonging to the genus Sphaeroma, commonly known as timber-boring organisms, have been recorded from different estuarine habitats of India (Nair, 1996). The mangrove forests are subjected to the attack of these timberboring organisms. Different aspects of the taxonomy and biology of these organisms have been studied (Nair, 1984, 1988, 1994) earlier. Wood-boring organisms of mangrove forests of India have also been reported (Ganapathi \& Rao, 1959; Nair \& Dharmaraj, 1980; Dharmaraj \& Nair, 1981; Santhakumaran, 1986; Rao, 1986). All these studies have been made on the exposed and submerged wood materials of marine and estuarine systems. Six species of sphaeromids such as Sphaeroma annandalei Stebbing, S. annandalei travencorensis Pillai, S. terebrans Bate, S. walkeri Stebbing, S. triste Heller and S. tuberculatum George occur along the Indian coasts. Of these six species, the first three have been reported from mangroves of Godavari Estuary (Ganapathi \& Rao, 1959; Rao, 1986), Talapady Mangroves in Mangalore (Dharmaraj \& Nair, 1981), Pichavaram Magroves (Nair \& Dharmaraj, 1980) and mangroves of Goa (Santhakumaran, 1986) along the Indian coast. No information is available on the distribution of wood boring organisms within the soil not only in the mangrove areas but also in various other estuarine or marine soil habitats. Sunil Kumar (in press) reported on the occurrence of sphaeromatids first ever from the subsoil of mangroves from Cochin area. The present paper describes a new habitat selection of Sphaeroma terebrans and its population structure and ecological distribution pattern in detail from the littoral subsoil of the mangrove ecosystem of Cochin backwaters, southern west coast of India.

\section{Materials and Methods}

Two mangrove locations were selected in Cochin backwater system. The first one is situated near to Cochin barmouth area and the second one at Elamkulam, about $15 \mathrm{~km}$ away from the first location (Figure 1). The fringing area of both locations is represented by mixed vegetation of mangrove species (Table 1). 


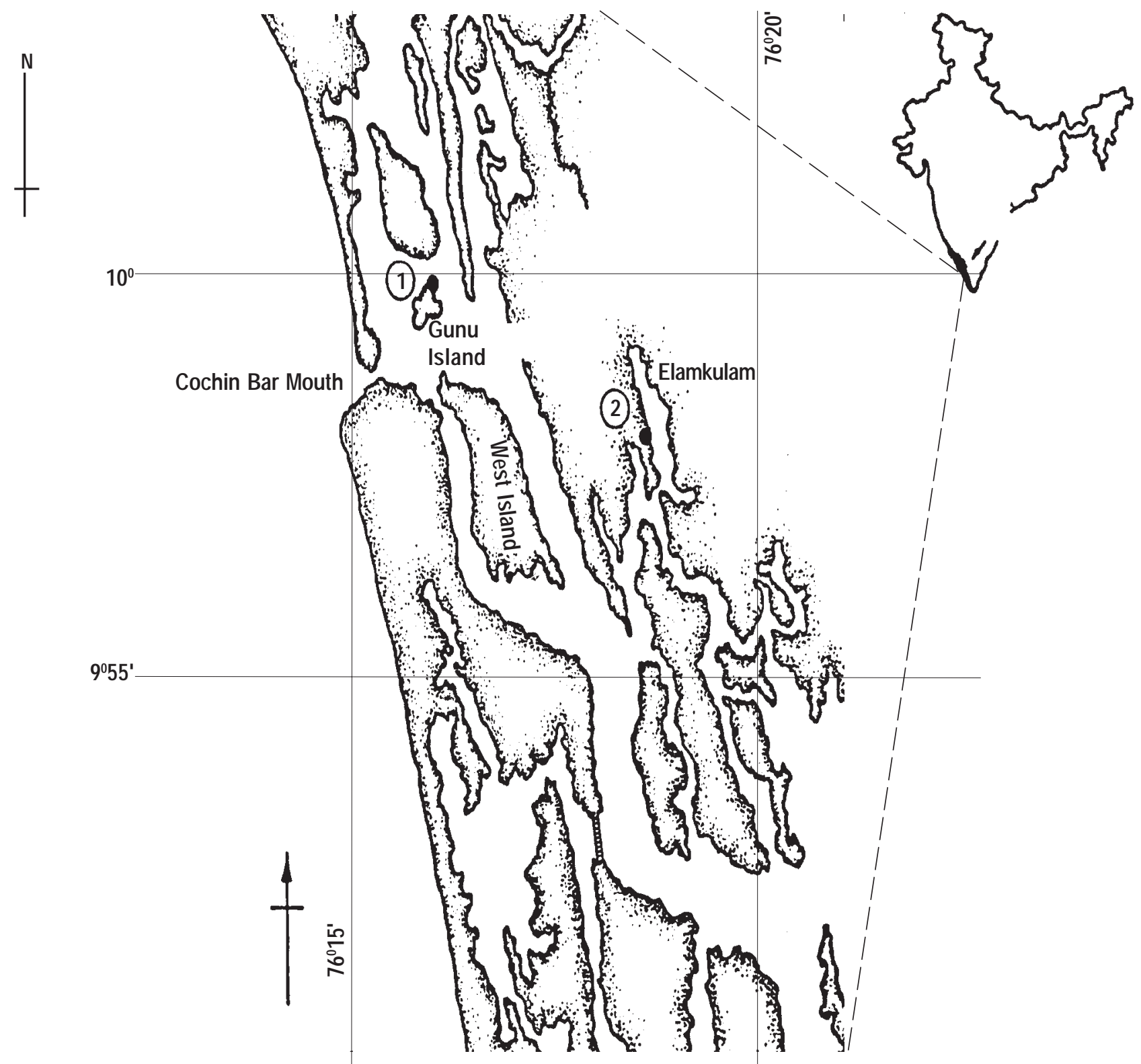

Figure 1. Map showing the location of the two stations.

Table 1. Distribution of mangrove species

\begin{tabular}{lll}
\hline Name & \multicolumn{2}{l}{ Locations } \\
& $\mathbf{1}$ & $\mathbf{2}$ \\
\hline Acanthus ilicifolius & + & + \\
Acrostrichum aureum & + & + \\
Avicennia officinalis & + & + \\
Bruguiera sp. & + & - \\
Cerebra odollom & - & + \\
Clerodendrum inerme & + & - \\
Derris trifoliata & + & + \\
Rhizophora mucronata & - & + \\
Rhizophora apiculata & + & + \\
\hline
\end{tabular}

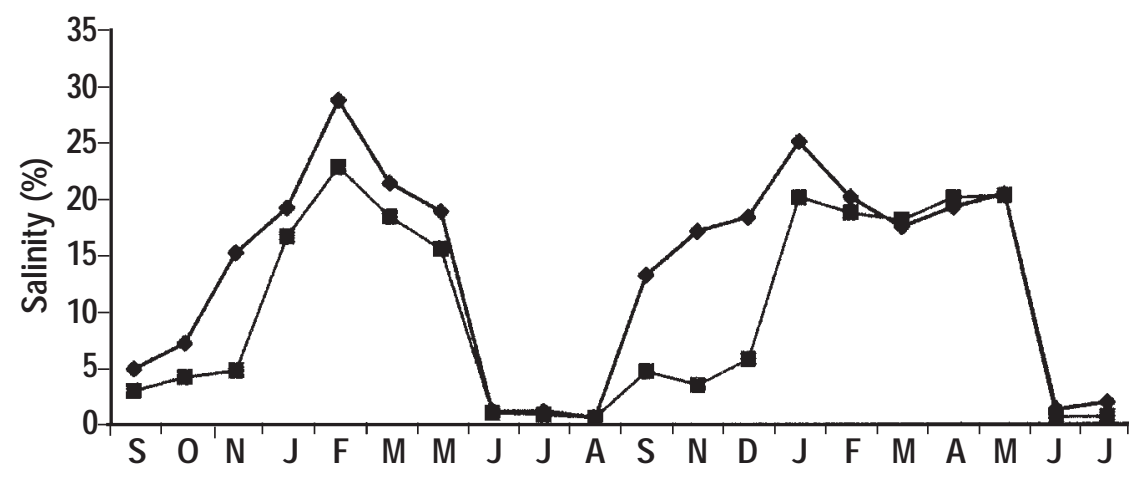

Figure 2. Monthly variation of salinity in the two locations 
Table 2. Sediment characteristics of the study area in different seasons (all values are in \% except pH).

\begin{tabular}{|c|c|c|c|c|c|c|c|c|c|c|c|c|c|c|c|}
\hline & \multicolumn{5}{|c|}{ Pre-monsoon } & \multicolumn{5}{|c|}{ Monsoon } & \multicolumn{5}{|c|}{ Post-monsoon } \\
\hline & sand & silt & clay & OC & $\mathrm{pH}$ & sand & silt & clay & OC & $\mathrm{pH}$ & sand & silt & clay & OC & $\mathrm{pH}$ \\
\hline & \multicolumn{5}{|c|}{ Location 1} & & & & & & & & & & \\
\hline HTL & 87.22 & 10.38 & 2.4 & 0.77 & 6.65 & 85.86 & 4.97 & 9.17 & 0.45 & 7.25 & 88.76 & 3.31 & 7.93 & 0.89 & 6.4 \\
\hline MTL & 88.76 & 7.62 & 3.62 & 0.44 & 6.8 & 80.92 & 11.38 & 7.7 & 0.55 & 7.1 & 77.24 & 2.66 & 20.1 & 0.81 & 6.6 \\
\hline \multirow[t]{2}{*}{ LTL } & 86.34 & 5.19 & 8.47 & 0.42 & 7.3 & 85.69 & 11.56 & 2.75 & 0.35 & 7.25 & 79.67 & 9.02 & 11.31. & 64 & 6.5 \\
\hline & \multicolumn{5}{|c|}{ Location 2} & & & & & & & & & & \\
\hline HTL & 73.33 & 11.1 & 15.57 & 1.53 & 6.75 & 70.4 & 20.47 & 9.13 & 1.44 & 7.59 & 64.12 & 15.04 & 20.84 & 1.65 & 6.3 \\
\hline MTL & 69.97 & 13.49 & 18.54 & 2.16 & 6.63 & 65.04 & 19.29 & 15.67 & 1.71 & 6.9 & 63.75 & 17.1 & 19.15 & 1.82 & 6.3 \\
\hline LTL & 62.37 & 14.07 & 23.61 & 2.35 & 6.8 & 47.77 & 44.28 & 7.95 & 2.37 & 7.4 & 51.86 & 12.81 & 35.33 & 2.36 & 6.4 \\
\hline
\end{tabular}

OC - Organic carbon; HTL - High tide level; MTL - Mid tide level; LTL - Low tide level

Three representative sites, in the low tide, mid tide and high tide areas, were also selected in each location. Soil samples were taken monthly from these three tidal areas during low tide period for two years. Triplicate collections were made in three tidal regions by using box corer $\left(120 \mathrm{~cm}^{2}\right)$ up to $20 \mathrm{~cm}$ depth and surface $15 \mathrm{~cm}$ soil was taken and pooled. The soil samples were sieved through $0.5 \mathrm{~mm}$ mesh sieve and organisms were collected and preserved in $5 \%$ neutral formalin for further study. The population density was expressed in $0.1 \mathrm{~m}^{2}$. Sand-silt-clay fractions of the soil were analysed (Krumbein \& Pettijohn, 1938). Besides the edaphic characteristics, the salinity, temperature, dissolved oxygen and $\mathrm{pH}$ have been measured using standard methods (Strickland \& Parsons, 1977). To establish the correlations between physico-chemical factors and distribution of organisms, whether significant or not, Pearson's correlation coefficient was employed.

\section{Results and Discussion}

\section{Ecological factors}

Of the various ecological factors, salinity was the most dominant fluctuating factor. The seasonal variation of salinity of the two mangrove areas is given in Figure 2. The sediment and water temperature fluctuated between $28.5-32^{\circ} \mathrm{C}$ and $30-33.5^{\circ} \mathrm{C}$ respectively at location 1 . At location 2 , soil temperature varied from $29.5-32.5^{\circ} \mathrm{C}$ and water temperature varied from $29.5-35^{\circ} \mathrm{C}$. The dissolved Oxygen content of water ranged from 1.62-4.23 $\mathrm{ml} / \mathrm{l}$ and $1.17-4.99 \mathrm{ml} / \mathrm{l}$ in locations 1 and 2 respectively.

The variations of sand-silt-clay fractions, organic carbon and $\mathrm{pH}$ of the sediment of the three tidal areas of two locations are given in Table 2. Sediment texture and organic carbon distribution showed significant variation in the two mangrove areas. Sediment type was sandy throughout the seasons at location 1.
It was clayey sand during pre-monsoon and post-monsoon and silty sand during monsoon period at location 2. Organic carbon varied from $0.35-0.89$ per cent at location 1 and $1.44-2.37$ per cent at location 2. The high organic carbon at location 2, in comparison to location 1 , is significantly related to the high percentage composition of minor fractions of sediment (silt and clay) in that area. The substantial relationship between organic carbon and minor fractions of sediment was established earlier in Cochin mangroves (Sunil Kumar, 1996).

Another significant observation made during the study was that the littoral soil of the both mangrove areas showed high amount of mangrove detritus. During the sieving process of soil sample, large amount of detritus and debris was collected and organisms were sorted out from these vegetal materials. No measurement was made regarding the quantity of detritus in mangrove soil. In the mangrove areas of Cochin the detritus production resulting from mangrove litter fall was $1500 \mathrm{~kg} / \mathrm{ha} /$ year (Rajagopal et al., 1985).

\section{Distribution and environmental relationship of Sphaeroma terebrans}

Monthly distribution and population density of the species is given in Table 3. No consistent pattern in distribution was observed in the two locations. The species was found to be distributed in all seasons of the year, showing the euryhaline nature. The maximum monthly population density recorded was $19 / 0.1 \mathrm{~m}^{2}$ at location 1 in the monsoon period and at location 2 in pre-monsoon period. Physico-chemical factors of both water and soil of mangrove environment showed no significant correlation with distribution of Sphaeroma terebrans. Correlation ' $r$ ' values between monthly density of species and water characteristics are given in Table 4 while ' $r$ ' values between 
Table 3. Monthly population density $\left(0.1 / \mathrm{m}^{2}\right.$ area) of Sphaeroma terebrans in the study area.

\begin{tabular}{|c|c|c|c|c|c|c|c|c|c|c|c|c|c|c|c|c|c|c|c|c|}
\hline \multirow{2}{*}{$\begin{array}{l}\text { Year } \\
\text { Month }\end{array}$} & \multicolumn{8}{|c|}{1989} & \multicolumn{8}{|c|}{1990} & \multicolumn{4}{|c|}{1991} \\
\hline & $S$ & 0 & $\mathrm{~N}$ & $\mathrm{~J}$ & $F$ & M & $M$ & $\mathrm{~J}$ & $\mathrm{~J}$ & $A$ & $\mathrm{~S}$ & $\mathrm{~N}$ & D & J & $F$ & $M$ & $A$ & $M$ & $\mathrm{~J}$ & $\mathrm{~J}$ \\
\hline & \multicolumn{20}{|c|}{ Location 1} \\
\hline HTL & 8 & - & 3 & 5 & - & - & - & 3 & 19 & 5 & 19 & 5 & 3 & - & 3 & - & - & - & - & - \\
\hline MTL & - & 8 & 5 & 3 & - & - & 3 & - & - & - & 11 & 11 & - & 3 & - & - & - & - & - & - \\
\hline \multirow[t]{2}{*}{ LTL } & - & - & - & - & - & - & - & - & - & - & - & - & - & 5 & - & - & - & - & - & - \\
\hline & \multicolumn{20}{|c|}{ Location 2} \\
\hline HTL & - & - & - & - & - & 8 & - & - & - & 3 & - & - & - & - & - & - & - & - & - & - \\
\hline MTL & - & - & - & 3 & 3 & 17 & 5 & 3 & - & - & - & - & - & - & - & 5 & 19 & 5 & - & - \\
\hline LTL & - & - & - & - & - & 19 & - & - & - & 5 & - & - & - & - & - & - & - & - & - & 5 \\
\hline
\end{tabular}

Table 4. Pearson's correlation values between monthly densities of Sphaeroma terebrans and water characteristics.

\begin{tabular}{llll}
\hline & Salinity & DO & Temperature \\
\hline Location 1 & & & \\
HTL & -0.330 & -0.091 & -0.320 \\
MTL & 0.091 & -0.350 & -0.144 \\
LTL & 0.298 & 0.205 & -0.148 \\
Location 2 & & & \\
HTL & 0.129 & 0.123 & -0.394 \\
MTL & $0.543^{*}$ & 0.437 & 0.348 \\
LTL & 0.092 & 0.116 & -0.447 \\
\hline
\end{tabular}

* Correlation is significant at 0.05 level
Table 5. Pearson's correlation values between season wise total densities of Sphaeroma terebrans and edaphic factors.

\begin{tabular}{llllll}
\hline Tidal level & Sand & Silt & Clay & OC & pH \\
\hline Location 1 & & & & & \\
HTL & -0.692 & -0.518 & 0.810 & -0.870 & 0.859 \\
MTL & -0.906 & -0.741 & $0.990^{*}$ & $1.000^{*}$ & -0.597 \\
LTL & -0.996 & 0.116 & 0.755 & 0.973 & $-0.998^{*}$ \\
Location 2 & & & & & \\
HTL & 0.939 & -0.544 & -0.317 & -0.446 & 0.206 \\
MTL & 0.981 & -0.927 & 0.351 & 0.972 & 0.058 \\
LTL & 0.676 & 0.066 & -0.454 & -0.473 & 0.425 \\
\hline
\end{tabular}

* Correlation is significant at 0.05 level

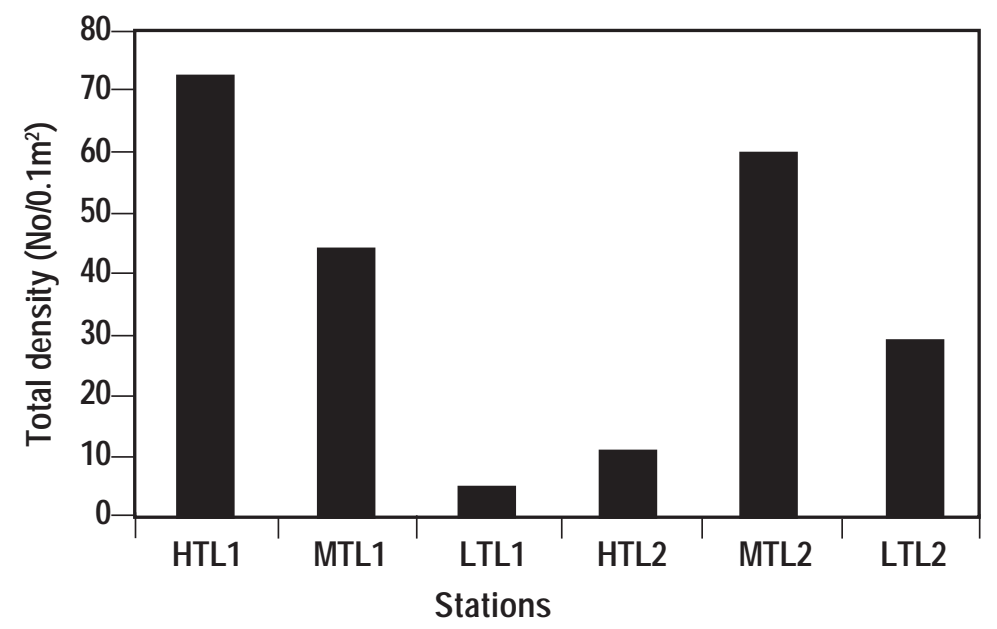

Figure 3. Population density of Sphaeroma terebrans in the three tidal areas of two locations. season wise (February-May for premonsoon, June-September for monsoon and OctoberJanuary for postmonsoon) total density and sediment characteristics are given in Table 5.

Substrate selection of the species was discernable in the intertidal area, accounting 95.9 per cent and 71 per cent of the total density in the area above low tide level at locations 1 and 2 respectively. Figure 3 shows the maximum density of organisms above the low tide area. However, a maximum of $19 / 0.1 \mathrm{~m}^{2}$ only in March 1990 in the low tide area of location 2 showed high density there than high tide area, but not than the mid tide region. In general the substrate preference of the species seems to be related to the tidal inundation process in which above low tide area of littoral zone is more exposed to water. In addition to this, little 
more consolidated substratum of this area, compared to low tide area also favoured the habitat preference of the species. In view of this, prolonged exposed areas of intertidal region unconditionally support populations of sphaeromids capable of tolerating periodic floods. The most cardinal factor favouring the occurrence of Sphaeroma terebrans in the subsoil of mangrove is the abundant presence of decomposing debris and detritus of mangrove origin. Since the species is a timber borer, these cellulose materials resulting from mangrove litter fall form an important diet of the organism. The litter fall and subsequent derivation of detrital particles in the soil owing to putrefaction, is a continuous process in the littoral area of mangrove ecosystem.

Cochin mangrove soil is enriched with more sand content with an admixture of little percentage of silt-clay together with excellent supply of detritus. Accumulation and incorporation of mangrove vegetative materials in soil is the most positive factor, rather than the textural composition of sediments such as sand, silt and clay along with organic carbon concentration, which can directly attract, and rendering the aggregation of sphaeromids in that area. This type of substratum in the littoral areas provides an ecological niche for the survival of Sphaeroma terebrans. Earlier works (Nair \& Dharmaraj, 1980; Dharmaraj \& Nair, 1981; Rao, 1986; Nair, 1984, 1988, 1994, 1996) on the timber destroying organisms indicate the occurrence of different species of Sphaeroma (S. annandalei Stebbing, S. annandalei travencorensis Pillai, S. terebrans Bate, $S$. walkeri Stebbing, $S$. triste Heller and $S$. tuberculatum George) in various exposed and submerged wooden materials including stems of mangrove tress of Indian estuarine and marine systems. These species can tolerate considerable dilution of seawater and, as a result of this, succeeded in spreading into brackish and even freshwater. The present study clearly suggests and substantiates the occurrence and distribution of Sphaeroma terebrans in the mangrove littoral subsoil of Cochin backwaters and the species can thrive well in that habitat for long-term period, even in the monsoon period in which fresh water flux was high. The occurrence of species in the $15 \mathrm{~cm}$ depth of mangrove substratum duly indicates the burrowing and penetration capacity of organism in the highly fertile soil.

Prior to this investigation, the sphaeromids were recorded from exposed and submerged timber structures of coastal areas as well as stems and dead stumps of mangrove tress. They penetrate deeper and deeper and destroy the timber structures along the estuaries, coastal waters and harbours of India within a brief period (Nair \& Thampy, 1980). Sphaeromids attack prop roots and stems of mangrove trees and the intensity of attack seem to depend on the degree of submergence (Rao, 1986). The present study evidently substantiates the selection of another suitable habitat, submerging and subsequent exposure to tidal water of the littoral soil of mangroves in association with tidal rhythm, by Sphaeroma terebrans. The adaptation of the species to the tidal inundation process prevailing in the area, its euryhaline nature, abundant supply of detritus and associated mangrove vegetative structures, exploitation of these food resources by organisms and avoidance of competition with other wood boring organisms appear to be virtually favouring the organism and its survival in the mangrove soil habitat.

\section{References}

Darmaraj, K. and N.B. Nair (1981). Timber boring animals of Talapady mangroves and adjoining areas with a record of Martesia sp. (Bivalvia: Pholadidae) boring into living tress. Mahasagar 14: 159162.

Ganapathi,P.N. and M.V.L. Rao(1959). Incidence of marine wood borers in the mangroves of the Gadavari Estuary. Current Science 28: 332.

Krumbein, W.C. and F.J. Pettijohn (1938). Manual of sedimentary Petrography. Appleton Century-Crofts, New York, 459 pp.

Rao, M.V.L. (1986). Notes on wood borers from the mangroves of the Godavari Estuary, India, pp. 579-588. In: Thompson, M.F., R. Sarojini and Nagabhushanam (Editors). Biology of Benthic Marine Organisms: Techniques and methods as applied to the Indian Ocean.

Molur S. and S. Walker (1998). Report of the Conservation Assessment and Management Plan workshop for Indian mangrove ecosystems (BCPP-Endangered Species Project). Zoo Outreach Organization/ CBSG India, Coimbatore.

Nair, N.B. (1984). The problem of marine timber destroying organisms along the Indian coasts. Proceedings of the Indian Academy of Science (Animal Science) 93(3): 203-223.

Nair, N.B. (1988). The problem of biodeterioration along the Indian coasts and its impact on fisheries. Proceedings of the Indian National Science Academy B54(1): 7-23.

Nair, N.B. (1994). Biodeterioration of cellulose materials in estuarine and insular biotopes. Proceedings of the Indian National Science Academy B60 (3): 217-228.

Nair, N.B. (1996). Destruction of timber structures in the estuarine systems of the south west coast of India, the Killayi and Beypore backwater. Journal of the Marine Biology Association of India 38(1\&2): 25-33.

Nair, N.B. and Dharmaraj (1980). Incidence of timber boring animals in the Vellar-Coleroon estuarine system. Current Science 49: 485-487. Nair, N.B. and Thampy (1980). Marine Ecology. Macmillan Company of India limited, Delhi, 352 pp.

Rajagopalan, M.S., C.P. Gopinathan, V.K. Balachandran and A. Kanagam (1986). Productivity of different mangrove ecosystem. Proceedings of the Symposium on Coastal Aquaculture MBAI 4: 10841087.

Santhakumaran, L.N. (1986). Marine wood bores of mangrove forests. UNDP/UNESCO Regional Training Course on Mangrove Ecosystems, Goa, India, pp. 109-124.

Sunil Kumar, R. (1996). Distibution of organic carbon in the sediments of Cochin mangroves, south west coast of India. Indian Journal of Marine Sciences 25: 274-276.

Sunil Kumar, R. (In Press). First report on the occurrence of sphaeromatids (Crustacea: Isopoda) from the soil habitat of Indian mangroves. Journal of the Marine Biology Association of India.

Strickland, J.D. and T.R. Parsons (1977). A practical handbook of seawater analysis. Fisheries Research Bulletin, Canada Ottawa 167. 